\title{
Challenges in Trade openness, Governance and Industrial Productivity in West African Economic and Monetary Union (WAEMU) Countries
}

\author{
Kossi AYENAGBO ${ }^{1} \&$ Mamadou BOUKARI ${ }^{1}$ \\ ${ }^{1}$ Department of Economics, University of Kara, LaRSEG/FaSEG, Togo \\ Correspondence: Kossi AYENAGBO, Department of Economics, University of Kara, LaRSEG/FaSEG, Togo.
}

Received: May 10, 2021

Accepted: July 7, 2021

Available online: September 3, 2021

doi:10.11114/aef.v8i5.5343

URL: https://doi.org/10.11114/aef.v8i5.5343

\begin{abstract}
Inward-looking development strategies can lead to marginalization and slow growth especially for the small African domestic markets. However, when weak economies try to participate in the global economy studies in Southeast Asia show they end with significant challenges. Therefore, this paper analyzed the effects of trade openness on industrial development in West African Economic and Monetary Union (WAEMU) countries. However, due to data availability, the study covered seven countries over the 1996 - 2018 period. The pooled-mean group method was used in the analysis. The results of the analysis showed that, in the long run, trade openness did not benefit the development of the industrial sector in all the countries studied. However, in the short run, the results revealed the specificities of each country. These short-run results showed that trade openness has a positive and significant effect on the industry added values observed in countries such as Burkina Faso, Niger and Togo. The results also showed that government inefficiency has a negative impact on the development of the industrial sector in the long -run for all the countries studied. Furthermore, the indicator capturing the degree of freedom of corruption had a positive impact on the development of the industrial sector in the short or long run. Therefore, active engagement with the forces of globalization need strategic approaches in their integration in developing countries.
\end{abstract}

Keywords: Africa, industrial development, trade openness, panel data, pooled-mean group method

JEL Classification Codes : H52, 055, L16, F18

\section{Introduction}

The globalization of the world economy is perhaps the most important trend which underlies all the current conditions for the economic development of a country (Ernest Aryeetey et al., 1998). It offers excellent opportunities to all countries, especially those in Sub-Saharan Africa, enabling them to increase their productivity and to accelerate their economic development. One of the most ways for Sub-Saharan Africa, and the West African Economic and Monetary Union (WAEMU), to participate in global economic integration is in the enhancing of their integration of these countries into international trade. In this system, international trade, opportunities are offered to countries as well as to individual companies.

Indeed, by creating large markets, international trade allows small businesses to reach their optimal size, which would lower average costs as well as to lower prices for consumers. However, the constraints to the development of the industrial sector in the WAEMU countries have remained enormous. We can cite, among others, the low availability and quality of physical and technological infrastructure, the absence of investment supervision structures and business assistance, the insufficiency of public and private investments, difficulties of access to commodity markets, the high costs of production factors, difficulties in accessing the so-called conventional bank financing, problems of political stability and corruption, weak capacity of institutions to carry out reforms and guarantee them, the inconsistencies in industrial policies, and the dysfunction of judicial systems. Indeed, the level of industrialization of a country is generally measured by the relative contribution of industrial production to GDP or by the proportion of people employed in a sector of activity. Thus, the rise of the high-added-value industrial sector lead to lower unemployment, increased labor productivity and, consequently, higher income (Alderson, 1999). Industrialization therefore plays a decisive role in the development of a country.

However, the level of industrialization of the WAEMU countries remains low. Despite their efforts, most of the WAEMU countries have encountered obstacles in their industrial development. The trade openness of these countries 
thus appeared as an opportunity to overcome the industrial constraints they face by pooling efforts. By trade openness we hereby mean the enlargement of the market within a given area by the elimination of tariff and non-tariff barriers, and the adoption of appropriate reforms to promote the development of trade through the free movement of people goods and services and capital.

According to Abdellatif et al. (2019), theoretical analyses argue that trade openness could boost the performance of the industrial sector, especially for countries that do not have a solid industrial base. This is how the WAEMU countries, each relying on its comparative advantages, should thus take advantage of the vast market to increase their industrial production and meet greater demands, develop their specializations, and get used to competition. In addition, this vast market offers opportunities for small businesses which will be able to increase their production and consequently lead to a consequent increase in national production. According to UNCTAD (2017), in 2016, intra-regional trade between the countries of the Economic Community of West African States (ECOWAS) amounted to 11.4 billion against 34.7 billion dollars for the countries of the Southern African Development Community (SADC). Moreover, the WAEMU countries have opened up considerably to the outside world through trade which has continued to increase. Total exports of goods by value of WAEMU countries stood at 14.986.8 billion in 2018, up 1.4\% from the level recorded in 2017 (Central Bank of West Africa States/ CBWAS, 2019). It is expected to stimulate growth and development through the intensification and diversification of industries in the community. Indeed, ECOWAS countries, like many regions of the world, see trade openness as a powerful tool to promote inclusive growth through the development of the industrial sector. However, despite numerous regional initiatives and trade agreements, the level of development of the industrial sector in this area remains very low overall. In view of the industrialization situation in the WAEMU countries and given their degree of trade openness to the rest of the world, a reflection can be carried out concerning the effects of these international exchanges on industrialization. As such, we ask the question, what is the effect of trade openness on the development of the industrial sector in the countries of the WAEMU zone? More precisely, has regional opening really had a positive or negative impact on the industrial sector between these countries?

Therefore, the objective of this research was set to analyze the effects of trade openness on industrial production in WAEMU countries. We hypothesized firstly that trade openness could positively affect the added-value of industrial production. Secondly, that improving the quality of governance through reduction of corruption and government efficiency are the main channels through which trade openness affects industrial production.

\section{Knowledge Gaps in Literature Review}

Theoretical analyses within the framework of international trade theory and growth theory provide evidence that trade openness positively affects the development of the industrial sector. Thus, the theoretical models of Krugman (1979a), Helpman and Krugman (1985) predicted that trade openness is likely to increase the productivity of firms by inducing economies of scale. According to the authors, trade liberalization leads companies to increase their exports, increase the scale of production and, in turn, lower production costs. Therefore, this mechanism leads to increased industrial production. However, according to Adam Smith (1776), international trade allows the expansion of the domestic market and the improvement of the division of labor and this leads to an increase in productivity. For David Ricardo (1817) and Heckscher-Ohlin (1933), the country's trade openness is determined by its level of productivity or its level of technology. Therefore, countries should specialize in producing goods which are most competitive.

According to the work of Topalova and Khandelwal (2011), trade openness leads to increased productivity either through trade competitiveness which is due to a reallocation of resources to the most productive sector or through entry of qualitative products and technological efficiency which ensures higher productivity. The work of of Rowthorn et al. (2004) and Graciela Chichilnisky (1994) showed that North-South trade would be beneficial for manufacturing industries in countries of the South. Kim's (2000) work on the link between trade openness and total factor productivity growth in Korean manufacturing showed that trade liberalization has a positive impact on productivity. By analyzing the effects of trade openness on the productivity of Ecuadorian manufacturing sectors in 2006, Wong's results show a positive and significant effect of trade openness on the productivity of manufacturing industries at the level of export-oriented industries in the 2000s following the implementation of trade reforms, but a decline in productivity after 2000 due to economic events. Dijkstra (2000) in examining the effects of trade liberalization on industrial development in Latin America, suggested that there may be a trade-off between static efficiency (X-efficiency, efficient allocation of resources) and dynamic efficiency in particular, for countries which do not have a developed industrial base. A review of the empirical evidence on several efficiency indicators shows that the effects of X-efficiency and efficient allocation of resources do occur but are not very strong. Other factors may be more important in generating productivity growth and structural change. Even for those Latin American countries (Argentina, Brazil, Mexico) with a more developed industrial base, the dynamic effectiveness of trade liberalization does not happen automatically. The work of Tahir et al. (2016) on the link between trade openness and the development of the industrial sector in six South Asian countries, showed that trade openness has a positive and significant influence on the industrial sector. According to these authors, 
this positive impact is due to the factors of production (human capital and investment) constituting an incentive effect which have contributed to the development of industrial added-value in these countries. These results are confirmed by the work of Kapri (2016), which showed similar the positive effects of trade openness on industrial productivity.

Studies on a Korean manufacturer, according to the above author, the liberalization of trade in China has led to productivity gains at the level of Korean manufacturing companies, such as a $1 \%$ cut in tariffs leads to a 0.92 increase in total factor productivity.

Abdellatif et al. (2019) studied in a context of trade liberalization, the impact of trade openness on the development of the industrial sector in developing countries: the case of Sub-saharan Africa by adopting the macro-econometric approach in panel data for the period 1980-2016. Thus, these results showed that trade openness positively and significantly influences the industrial sector of the countries of the region considered. Other determinants such as education and macroeconomic stability also contribute to the development of the sector. The decomposition of the sample into groups of countries according to their level of income made it possible for this study to arrive at heterogeneous results between the Sub-saharan countries on the impact of trade openness on the performance of the industrial sector.

\section{Some Stylized Facts about Trade Openness and Industrialization}

Between 1996 and 2018, it is observed external trade liberalization within WAEMU countries. The latter is characterized by open trade in countries that tend to impose only low barriers to entering its market. This also reflects the emphasis that has been placed on trade facilitation, trade promotion and support for improving competitiveness. Regarding the evolution of the degree of trade openness, it is observed over the period from 1996 to 2018 three (03) phases of evolution of the activity of industrial production. From 1996 to 1998, a sharp drop in industrial added-value was observed reaching a lower level of 18.19489 as a percentage of GDP in 1998. Between 1998 and 2000, there was a strong growth in industrial added-value with a value from 20.80 as a peak in 2000 and this production remained stable until 2007 but a fall was observed from the years 2008. This downward trend in industrial production could be explained by the advent of the financial crisis of 2008 (the subprime crisis) which affected several countries around the world. There is more or less a linear upward trend over the period from 2009 to 2012. On the other hand, the trend remains relatively normal until 2018. This shows that there is still a lot of effort to be made in the WAEMU zone on structural transformation issues.

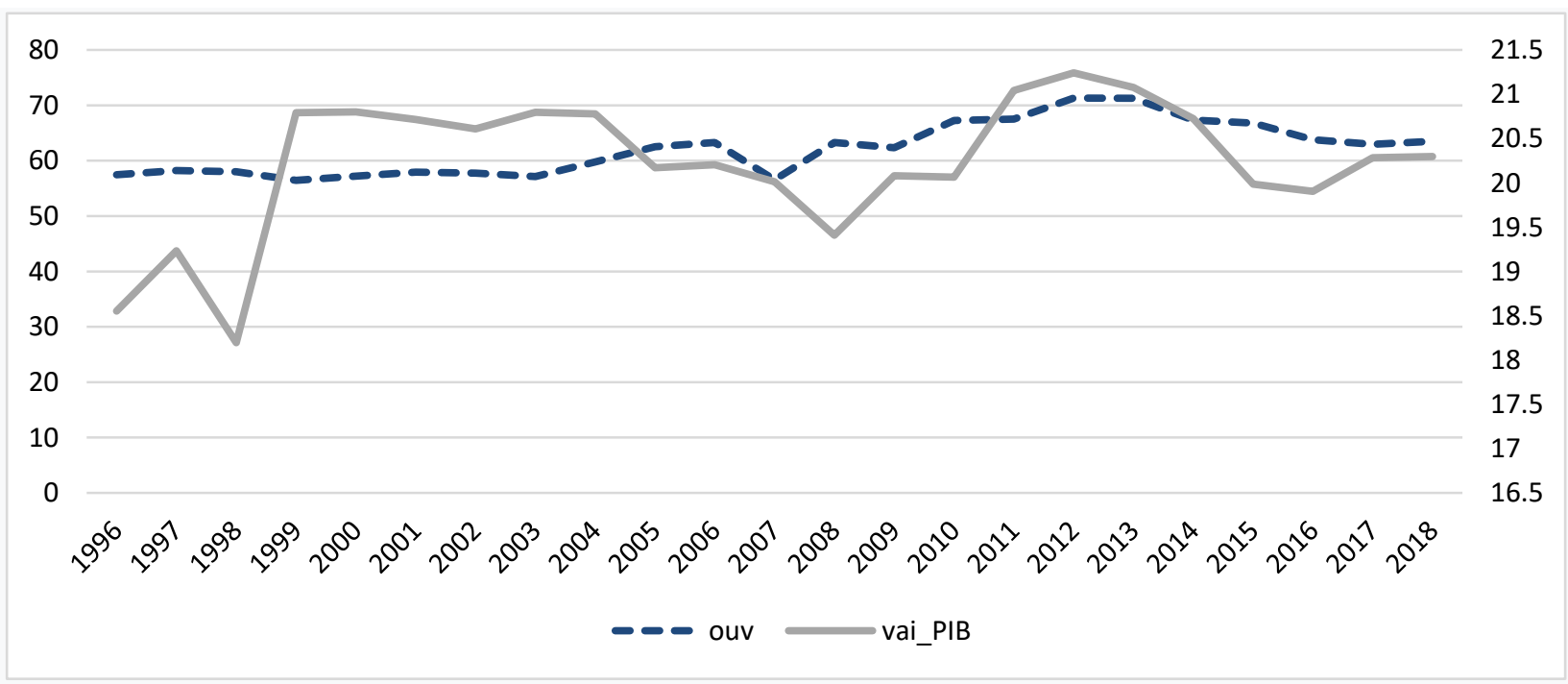

Figure 3.1. Figure 1 shows the evolution of the added-value of industrial production as a percentage of GDP and the degree of trade openness as a percentage of GDP within the WAEMU countries from 1996 to 2018.

Source: Author based on data from the World Bank's WDI

\section{Methodology}


The theoretical framework of the model is based on developments in endogenous growth theories.

Therefore, using Cobb Douglas production function to analyze this subject is justified as follows. Often, in order to present and analyze the economic growth of a country or group of countries such as the WAEMU countries, which are open to commerce, it is sufficient to apply formulas that have already proven to be reliable in market economies. This is the case, especially with the Cobb Douglas theoretical model (production function). The analytical possibilities offered by this function consist in juxtaposing potential and actual growth. When technical progress is such that there is both an elasticity of substitution $\sigma$ between capital and labour equal to unity at any point in the function and constant returns to scale. So, to analyze the effect of trade openness on industrial development in the WAEMU zone, we are inspired by the Cobb Douglas production function, whose technological progress is neutral in the sense of Hicks:

$$
y_{t}=A_{t} K_{t}^{\alpha} L_{t}^{\beta}
$$

$$
\text { Where } 0<\alpha<1,0<\beta<1, \alpha+\beta=1 \text {, }
$$

- $y_{t}$ represents the total output (national income or GDP) of the industrial sector at time $t, \mathrm{~A}_{\mathrm{t}}, \mathrm{K}_{\mathrm{t}}$ and $\mathrm{L}_{\mathrm{t}}$ denote respectively the total factor productivity, the capital stock and the labor stock

- $\alpha$ and $\beta$ represent the parameters less than unity.

\subsection{Specification of the Empirical Model and Description of Variables}

We follow the methodological framework of Crespi and Geuna $(2008,2005)$ and Tahir $(2016)$, to specify the empirical model. In order to test the effect of trade openness on industrial production, we used econometric estimates with data from 07 WAEMU countries covering the period 1996-2018.

The following equation is considered:

$$
y_{i t}=\alpha_{0}+\alpha_{1} y_{i t-1}+\alpha_{2} o u v_{-} \operatorname{com}_{i t}+\alpha_{3} i n v_{i t}+\alpha h_{i t}+\alpha X_{i t}+u_{i t}
$$

In order to identify the transmission channels of trade openness, we sought to analyze the interactive effects between the degree of freedom from corruption and trade openness on industrial development. For this we establish the following equation:

$$
y_{i t}=\alpha_{0}+\alpha_{1} y_{i t-1}+\alpha_{2} \text { ouv } * \operatorname{corrup}_{i t}+u_{i t}
$$

Where: $\mathbf{y}_{\mathbf{i t}}$, an industry's contribution to growth is generally measured by industrial added-value which reflects the development and performance of the industrial sector. We measure the development of industrialization by the industrialization rate, which is the ratio of the added-value of industries to the GDP (Ngoa Tabi and Atangana Ondoa, 2013; Hossein and Weiss, 1999). ouv_com: designates the commercial opening captured as the ratio between total export and import to GDP (RODRIGUEZ \& RODRIK, 2000); inv represents Investment and is captured by the Gross fixed capital formation (GFCF) in percentage of GDP at constant price. These are all explanatory variables that will allow us to assess the influence of modernity on industrialization. tx_GDP: is the GDP growth rate (annual\%) in level and squared, in order to test the U-shaped relationship between GDP and industrialization or deindustrialization postulated by Clark (1957). Institutional quality: Industrial development is based on institutional factors that promote a stable politico-legal climate in order to encourage the business climate and promote investment. We captured it by the Corruption Perception Index (corrup) and the government effectiveness (effic). The Corruption Perception Index is constructed from several optional surveys of experts commenting on their perception of the level of corruption in the public sectors. Countries are ranked on a scale from 0 to 10; 0 indicates a high degree of corruption and 10 indicates a low degree of corruption. We expect a negative sign (-) for the coefficient of corrup. The government effectiveness (effic), is a variable that assesses the quality of services, the quality of bureaucracy, the competence of civil servants, the policy and the government's credibility in respecting its commitments to economic and political actors. This variable is between -4.5 and 4.5 where a high value indicates high government efficiency and therefore attracts foreign investors. The expected sign is positive (+).

\subsection{Presentation of the Study Sample and Data Source}

The sample is composed of the countries of the West African Economic and Monetary Union (WAEMU). These countries are: Benin, Burkina Faso, Côte d'Ivoire, Guinea-Bissau, Mali, Niger, Senegal and Togo. The study period 
covered annual analysis from 1996 to 2018. For reasons of data availability, the study will cover seven (07) countries as Guinea-Bissau will be excluded during econometric estimates. In addition, the choice of these countries is justified by the fact that they have the same economic characteristics, the same historical past (colonization and sub-regional integration) and also have the same monetary policy regime. We use data from several sources (World Development Indicators, perspective.usherbrooke.ca/bilan database, Worldwide Governance Indicators).

\subsection{Estimation Techniques}

\subsubsection{Stationarity Tests}

Before moving on to the estimations, we studied the stochastic properties of the data, in particular the unit root tests. Stationarity tests are necessary to avoid the spurious regression problem. For Panel data, these tests constitute hypotheses made on the dependence of interindividual error terms (N'guessan, 2019; Hurlin and Mignon, 2007). Authors such as Hurlin and Mignon (2007) report the fundamental differences between Panel and time series stationarity tests. With regard to the tests of stationarity on time series, the statistical tests have non-standard and conditional asymptotic distributions specific to each model, while the statistical tests of stationarity of the Panel models admit the asymptotic distribution of laws normal.

The first empirical results were tested by Levin and Lin (1992). To solve interindividual correlation problems, we very often use two tests. These are the first-generation tests developed by Maddala and Wu (1999) and a second-generation test by Pesaran (2007).

\subsubsection{Cointegration Test}

Usually, time-series cointegration tests are used. However Pedroni $(1995,1999,2001,2004)$, Kao (1999) and (Westerlund et al., 2007) have proposed cointegration tests that apply to Panel data. The use of cointegration techniques in panel data makes it possible to test for the presence of long-term relationships between integrated variables. Pedroni offers seven (7) statistics to test cointegration in panel data: four are based on the within dimension (intra) and three are based on the between (inter) dimension (Kos à Mougnol and Kamajou, 2016). The advantage of the Westerlund test is that it can be applied to unbalanced panels and, is applicable even in case of inter-individual dependencies, with the bootstrapping procedure.

\subsubsection{Pooled Mean-Group Method (Aggregate Group Average)}

The Pooled Mean Group estimator, developed by Pesaran, Shin and Smith $(1998,1999)$ is part of the class of dynamic panel models in which it is assumed that the number of observations $\mathrm{T}$ is as large as that of individuals $\mathrm{N}$. This estimator admits that the model constant, as well as the short-term coefficients and the variances of the errors, can differ between individuals. The method is based on the dynamic panel specification of the Auto Regressive Distributive Lags (ARDL) model of the following form:

$$
y_{i t}=\sum_{j=1}^{p} \gamma_{i j} y_{i, \mathrm{t}-\mathrm{j}}+\sum_{j=0}^{q} \delta_{i j} X_{i, \mathrm{t}-\mathrm{j}}+\mu_{i}+\varepsilon_{i t}
$$

Where the number of individuals $\mathrm{i}=1,2, \ldots \ldots \mathrm{N}$; the number of period $\mathrm{t}=1,2, \ldots \ldots \mathrm{T}$; is a vector with explanatory variables; are the vectors of the coefficients; are scalars and is the country specific effect. A main characteristic of cointegrated variables is their reaction to any deviation from the long-term equilibrium. This characteristic implies an error correction model in which the short-term dynamics of the system variables are influenced by the deviation from the equilibrium. In this case, equation [1] can be re-parameterized as follows:

$$
\Delta y_{i t}=\phi_{i}\left(y_{i, \mathrm{t}-1}-\theta^{\prime}{ }_{i} X_{i t}\right)+\sum_{j=1}^{p} \gamma_{i j} \Delta y_{i, \mathrm{t}-\mathrm{j}}+\sum_{j=0}^{q} \delta_{i j} \Delta X_{i, \mathrm{t}-\mathrm{j}}+\mu_{i}
$$

The parameter is the rate of error correction of the adjustment term (adjustment coefficient). If, then there is no evidence of the presence of a long-term relationship. If, then there is an error correction, which implies that the variables and are cointegrated. This parameter is supposed to be significantly negative under the previous assumption that the variables show a return to long-run equilibrium.

\section{Empirical Results}

5.1 Analysis of Descriptive Statistics 
In analyzing the results of econometric estimations, it is important to take a look at the descriptive analysis of the natural behavior of the data available to us. At first glance, we see a large gap between certain variables such as industrial added-value in US \$ (constant value), trade openness, gross fixed capital formation, and institutional variables (government efficiency), growth rate of GDP. We used the industrial added-value as our dependent variable. On average, this dependent variable is about $20 \%$ of the GDP of the WAEMU countries. The minimum value was recorded in Niger (11.26) in 2006 and the maximum in Benin (29.72) in 2001. The Min and Max values of the gross fixed capital formation variable which represents the investments supposed to boost industrialization are, respectively, 8.25 and 38.89 in percentage of GDP. The minimum was recorded in Ivory Cost and the maximum in Niger.

Togo has the highest ratio of openness (118.10\%) compared to the lowest level recorded by Burkina Faso (30.73\%) over the period of study.

Table 1. Descriptive statistics of the model variables

\begin{tabular}{|c|c|c|c|c|c|}
\hline Variable & Obs & Mean & Std. Dev. & Min & Max \\
\hline Industrial Added Value & 161 & 20.22 & 3.74 & 11.26 & 29.72 \\
\hline Trade openness ratio & 161 & 62.16 & 16.45 & 30.73 & 118.10 \\
\hline GDP growth & 161 & 4.67 & 3.06 & -4.39 & 15.38 \\
\hline Gross capital Formation & 161 & 20.38 & 6.60 & 8.25 & 38.89 \\
\hline Corruption index & 161 & 2.91 & 0.43 & 2.09 & 3.91 \\
\hline Government Effectiveness & 133 & -0.75 & 0.35 & -1.55 & 0.08 \\
\hline
\end{tabular}

Source : Author

The government effectiveness is in units of a standard normal distribution, with mean zero, standard deviation of one, and running from approximately -2.5 to 2.5 , with higher value corresponding to better governance. The average value of this indicator is equal to -0.75 , showing that the efficiency level of the WAEMU countries is bad.

\subsection{Unit root test results}

To determine the order of integration of the series studied, we retained one of the most widely used unit root tests namely the test of Levin-Lin and Chu (2002). The test suggests that only the variable EFF_GOV (government efficiency) is stationary in level while the other variables have a unit root. Note that all these variables are stationary in first difference. This result allows us to conclude that the conditions for implementing the ARDL type cointegration model for series I (0) or I (1) are met.

Table 2. Unit root test of study variables (stationarity)

\begin{tabular}{lcccc}
\hline & \multicolumn{2}{c}{ Levin-Lin and Chu Stationarity test } & \multicolumn{2}{c}{ In first difference I(1) } \\
\cline { 2 - 5 } Variables utilized & \multicolumn{2}{l}{$\begin{array}{c}\text { In Level I(0) } \\
\text { Decision }\end{array}$} \\
\hline & 0.089 & Non stationnary & 0.000 & stationnary \\
Levin-Lin and Chu stationarity test (VAI) & 0.604 & Non stationnary & 0.000 & stationnary \\
GBP Growth rate (TX_GDP) & 0.370 & Non stationnary & 0.000 & Stationnary \\
Trade Openness (OUVCOM) & 0.448 & Non stationnary & 0.000 & Stationnary \\
Investment (GFCF) & 0.002 & Stationnary & 0.000 & Stationnary \\
Government efficiency EFF_GOV) & \multirow{2}{*}{0.001} & Stationnary & 0.000 & Stationnary \\
Corruption freedom index (corrup) & & & &
\end{tabular}

Source : Author

\subsection{The Results of the Cointegration Test}

The series relating to the variables OUVCOM. TCR_GDP; GFCF and VAI being integrated of order 1. The second step of our empirical approach consists in testing the existence of a possible cointegration relation. The cointegration test used is that proposed by Pedroni (1999). Indeed the cointegration of the variables depends on the value of the probability associated with each test statistic. All statistical tests reject the null hypothesis of non-cointegration. In other words, the series are cointegrated. The second step is to estimate the long-term relationship. Following our approach, we will make the estimates using the "Pooled Mean Group" method. 
Table 3. The results of the cointegration test of exogenous variables with dependent variable

\begin{tabular}{lcc}
\hline & Pedroni cointegration test & P-value \\
\cline { 2 - 3 } Modified Phillips-Perron t & t- Statistics & 0.060 \\
Phillips-Perron t & 1.52 & 0.000 \\
ADF t & -4.20 & 0.000 \\
\hline
\end{tabular}

Source : Author

\subsection{The Results of the Estimates by the Pooled-Mean Group (PMG) Method}

ARDL-type regressions show that all the variables are cointegrated. Indeed, the adjustment coefficient is negative and significant. Industrial added-value and trade openness (ouv_com) evolve together in the long term. There is therefore a stable equilibrium relationship between trade openness and industrial added value. According to the results obtained in the long run, trade openness is not beneficial for the growth of production industry in all seven WAEMU countries considered. Thus, when trade openness increases by one point, this leads to a decrease of 0.16 point in industrial value added. This result reflects the weak capacity of industries in the zone to face competition from products from foreign industries and also the small number of manufacturing industries established in the zone. On the other hand, in the short run, trade openness has a positive impact on the growth of industrial added-value in all the countries studied. These results corroborate those of Tahir et al (2016). Topalova and Khandelwal (2011) and Njikam (2009) which show that trade openness has a positive and significant influence on the industrial sector. Specifically, in the short run, trade openness has a positive and significant impact on industrial development in countries like Burkina Faso. Niger and Togo. In the case of Togo, the one point increase in trade openness leads to 0.23 point increase in industrial added value. This effect is greater for the case of Burkina Faso and Niger and respectively of the order of $0.44 \%$ and $1.15 \%$. These results reflect the partial removal of a number of tariff barriers in these countries.

With regard to the investment captured here by gross fixed capital formation (gfcf), it has a positive and significant long-term effect on the growth of industrial added-value for all of the seven WAEMU countries. This result does not collaborate with the work of Rodrik (1992) and Miyagiwa and Ohno (1995) who show that trade openness reduces the market share of domestic firms which encourages them to invest less. This has a negative impact on their productivity and therefore on their competitiveness. However. the contribution of public and private investment to industrial development in this study could be explained by the increase in the public investment effort due to the fall in public debt, the fall in borrowing costs and the increase in revenue in all WAEMU countries. However, the opposite effect occurs in the short -run in the countries studied except Benin. The results show that investment has a negative effect on industrial productivity in the short run. This result shows that most industries do not have access to credit. Thus, the narrowness of the volume of loans granted to local businesses is explained on the one hand by the presence of information asymmetry which is a result of the unavailability of strong resources to guarantee these loans and of another side of the weak development of the banking system in this region. This result is aligned with the study by Fjos. Grunfeld and Green (2010).

In the short run, government efficiency evolves in the opposite direction with the industrial added-value of all WAEMU countries. This shows that the government in these countries is making efforts in terms of supervision and orientation of administrative files. It is about the creation of industries or efforts to improve the business climate. On the other hand, in the short run, the coefficient assigned to government efficiency is positive and significant for Ivory Cost and Senegal and has the opposite effect for Benin. In the long -run, the GDP growth rate is positive but not significant. This shows that the growth rate of GDP does not contribute substantially to industrial added-value for all of the seven countries of the WAEMU zone studied. On the other hand, in the short -run, the GDP growth rate has a positive and significant impact on industrial added-value in Niger and leads to an increase in it. This result can be considered reasonable insofar as the gains from trade liberalization (whether in terms of industrial development or welfare) are assumed to be concentrated in countries with advanced income and the most competitive such as high growth countries.

Tables 4. Results with the Pooled-Mean Group estimator: PMG

\begin{tabular}{llc}
\hline & Long-Run impact & \\
\hline Variables & & Coefficients (Z-Value) \\
\hline Trade Openness & (IOUVCOM) & $-0.16^{* *}$
\end{tabular}




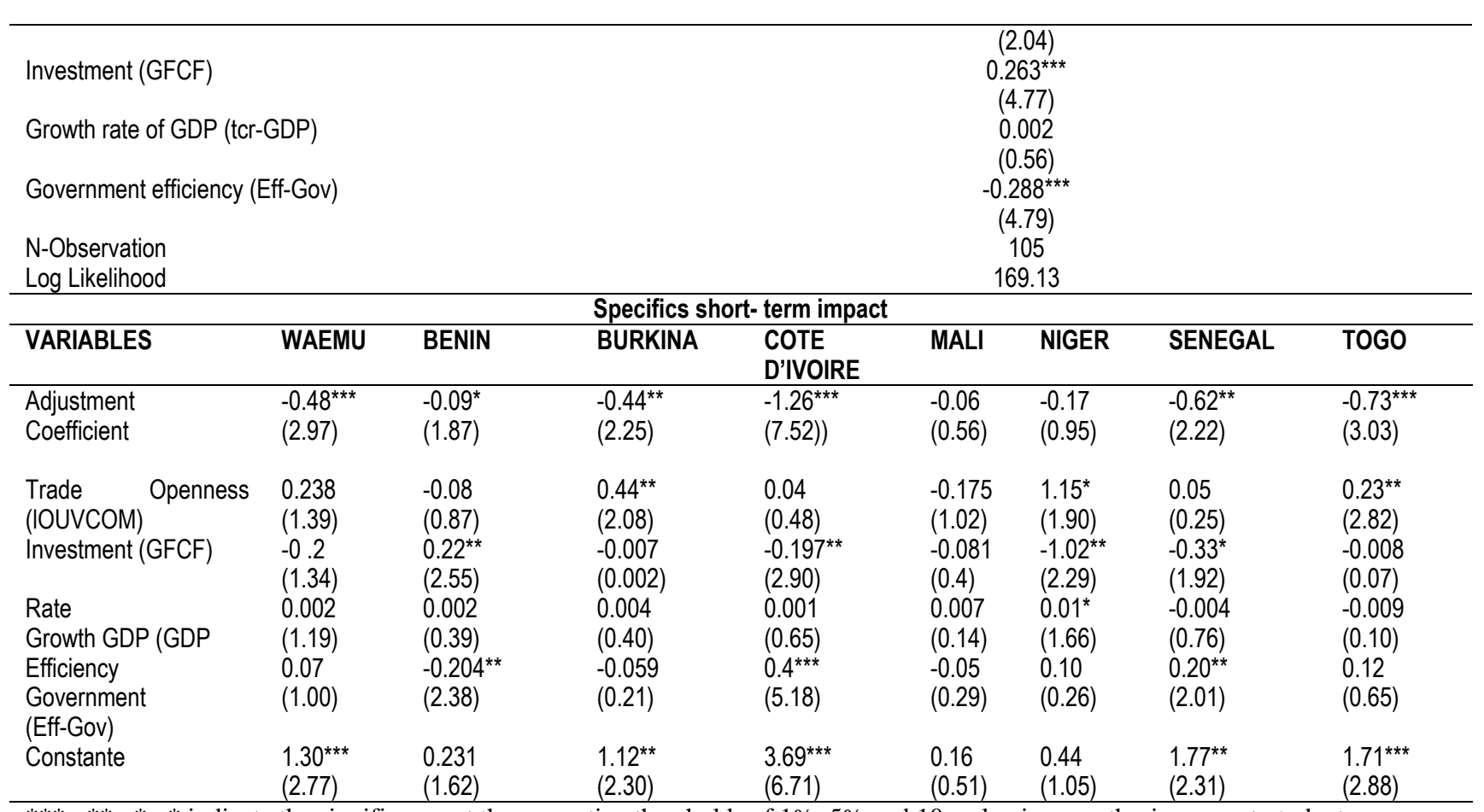

***;**;*;* indicate the significance at the respective thresholds of $1 \% ; 5 \%$ and 10 . value in parenthesis means t-student

$* * * ; * ; *$ indicate the significance at the respective thresholds of $1 \% ; 5 \%$ and 10 . value in parenthesis means t-Student

Source : Author

The results of the interactive analysis between trade openness and the degree of corruption are presented in the table below. This result shows that the channel through which trade openness is favorable to long-term industrial productivity growth is the degree of freedom from corruption. Estimates show that in the long- run, trade openness has a positive and significant effect on industrial productivity through corruption. When the degree of corruption decreases by one point, it results in an increase in added-value of $0.04 \%$. This reflects the effect of corruption on the business climate and plays an important role on industrial production. Thus, the work done on public investment in Sub-saharan Africa shows that when countries control corruption, it is ensure political stability and public investment would be revived and this could increase industrial productivity. Likewise, in the short-run, trade openness has a positive and significant impact on the development of the industrial sector in Côte d'Ivoire by reducing the degree of corruption.

Table 5. Results of the interactive effect between corruption and trade openness on industrial added -value

\begin{tabular}{|c|c|c|c|c|c|c|c|c|}
\hline \multicolumn{9}{|c|}{ Long -run Impact } \\
\hline Variables & & & \multicolumn{6}{|c|}{ Coefficients (Z-Value) } \\
\hline OUV*CORRUP & & & \multicolumn{6}{|c|}{$\begin{array}{l}0.04^{* * *} \\
(3.10)\end{array}$} \\
\hline N-Observation & & & \multicolumn{6}{|c|}{$\begin{array}{c}(3.10) \\
154\end{array}$} \\
\hline Log Likelihood & & & \multicolumn{6}{|c|}{194.83} \\
\hline \multicolumn{9}{|c|}{ Sepecific Short -run Impact } \\
\hline VARIABLES & WAEMU & BENIN & BURKINA & $\begin{array}{l}\text { COTE } \\
\text { D'IVOIRE }\end{array}$ & MALI & NIGER & $\begin{array}{l}\text { SENEG } \\
\text { AL }\end{array}$ & TOGO \\
\hline $\begin{array}{l}\text { Adjustment } \\
\text { Coefficient }\end{array}$ & $\begin{array}{l}-0.38^{\star \star *} \\
(8.46)\end{array}$ & $\begin{array}{l}-0.31^{* *} \\
(2.57)\end{array}$ & $\begin{array}{l}-0.44^{* *} \\
(2.25)\end{array}$ & $\begin{array}{l}-0.38^{* * *} \\
(3.04))\end{array}$ & $\begin{array}{l}-0.23^{*} \\
(1.68)\end{array}$ & $\begin{array}{l}-0.33^{\star *} \\
(2.25)\end{array}$ & $\begin{array}{l}-0.33 \\
(1.62)\end{array}$ & $\begin{array}{l}-0.59^{\star * *} \\
(3.94)\end{array}$ \\
\hline OUV*CORRUP & $\begin{array}{l}0.02^{*} \\
(1.79)\end{array}$ & $\begin{array}{l}0.05 \\
(0.59)\end{array}$ & $\begin{array}{l}0.03 \\
(0.66)\end{array}$ & $\begin{array}{l}0.06^{\star *} \\
(2.52)\end{array}$ & $\begin{array}{l}0.03 \\
(0.96)\end{array}$ & $\begin{array}{l}-0.01 \\
(0.22)\end{array}$ & $\begin{array}{l}-0.03 \\
(0.89)\end{array}$ & $\begin{array}{l}0.03 \\
(1.61)\end{array}$ \\
\hline Constant & $\begin{array}{l}0.94^{\star * *} \\
(9.35)\end{array}$ & $\begin{array}{l}0.82^{* *} \\
(2.57)\end{array}$ & $\begin{array}{l}1.2^{* *} \\
(2.55)\end{array}$ & $\begin{array}{l}1.4^{\star * \star} \\
(2.88)\end{array}$ & $\begin{array}{l}0.59^{*} \\
(1.69)\end{array}$ & $\begin{array}{l}0.70^{* *} \\
(2.11)\end{array}$ & $\begin{array}{l}0.89^{*} \\
(1.65)\end{array}$ & $\begin{array}{l}1.33^{\star * *} \\
(3.90)\end{array}$ \\
\hline
\end{tabular}

Source : Author

\section{Discussions and Conclusions}

This research enriches the economic literature on the effects of trade opening. Most studies have analyzed the microeconomic and macroeconomic consequences of trade openness and the enrollment rate in secondary education but 
do not often address the issue in terms of industrial production in WAEMU countries. On the other hand, this research reveals the channels through which trade openness manifests.

The econometric analyzes showed that in the long -run trade openness is not beneficial for development of the industrial sector in all the countries studied. However, in the short-run, the results reveal specificities to each country. In the short -run, trade openness has a positive and significant effect on the industrial added-value observed in countries such as Burkina Faso. Niger and Togo. Another channel through which trade openness can positively affect the development of the industrial sector is through the quality of institutions. Indeed. the results show that government inefficiency negatively impacts the development of the industrial sector in the long -run for all the countries studied. Thus, in the short -run, this effect was more pronounced in Benin. The indicator capturing the degree of freedom of corruption was found to have a positive impact on the development of the industrial sector. The research was limited by the availability of data as indicated in the results section.

In order to promote good development of the industrial sector in the WAEMU zone. the governments and decision-makers of these countries must implement a kind of protectionism in order to protect their infant or fragile industries from foreign competition. This is one way of enhancing local development of industries as they mature for competitive trade opening. However, these protectionist trade policies can prove difficult to implement by because they shall contradict the rules of the World Trade Organization. Therefore, developing nations should work out stimulus models to spur progressive industrial development. This can be by interactively customising and applying the above findings to improve the quality of governance and institution establishment. Studies of these models in Southeast Asian situations show that the sub-Saharan Africa policy-makers could learn and adapt and customise them for accelerated profitable globalization participation.

\section{References}

Abdellatif, C., Hassane, Z., Asma, Z., \& Mariem, C. (2019). Trade Openness and Industrial Sector Development in Developing Countries: The Case of Sub-Saharan Africa, Chapter in the book Openness, Productivity and Economic Growth in Morocco. Edited by Chatri Abdellatif, Published by Laboratory of Applied Economic » (Mohammed V Univ.) \& Policy Center for the New South, ISBN (WEB): 978-9920-37-593-1. Retrieved from https://www.researchgate.net/deref/http\%3A\%2F\%2Fwww.labeamse.com\%2F2019\%2F04\%2FOPCM10.html

Adam, S. (1776). Adam Smith's Theory of International Trade, In : H. Myint in, 'Adam Smith's Theory of International Trade in the Perspective of Economic Development. Economica New Series, 44(175), 231-248. Published By: Wiley. https://doi.org/10.2307/2553648

Alderson, A. (1999). Explaining deindustrialisation: globalization. failure. or success? American Sociological Review, 64(5), 701-721. https://doi.org/10.2307/2657372

Central Bank of West African States /CBWAS (2019). The WAEMU Surveillance framework: reforms to foster public debt sustainability, March 2019, IMF Country Report No. 19/91.

David, R. (1817). David Ricardo's theory of international trade, In: Ukwandu, 2015 'David Ricardo's theory of comparative advantage and its implication for development in Sub-Saharan Africa: a decolonial view. Retrieved from http://hdl.handle.net/2263/58163

Dijkstra, A. G. (2000). Trade Liberalization and Industrial Development in Latin America. World Development, Elsevier, 28(9), 1567-1582. https://doi.org/10.1016/S0305-750X(00)00040-1

Ernest, A., Julius, C., Machiko, N., \& Beatrice, W. (1998). Strengthening Africa's Participation in the Global Economy', Report from expert consultative meetings organized by the United Nations University and the African Economic Research Consortium. Retrieved from https://archive.unu.edu/hq-area4/globafrica.html

Fjos, S., Grunfeld, L., \& Green, C. (2010). SMEs and Growth in Sub-Saharan Africa-Identifying SME Roles and Obstacles to SME Growth. MENON Business Economics, MENON Publication No. 14/2010, Oslo, Norway.

Graciela, C. (1994). North-South Trade and the Global Environment. The American Economic Review, 84(4), 1851-874. American Economic Association.

Heckscher, O. (1933). International trade theory, In: Edward E.Leamer and JamesLevinsohn in Chapter 26 International trade theory: The evidence. Handbook of International Economics, 3, 1339-1394, https://doi.org/10.1016/S1573-4404(05)80006-1

Helpman, E., \& Krugman, P. (1985). Market structure and foreign trade : Increasing returns. imperfect competition. and the international economy. MIT press. Retrieved from

https://mitpress.mit.edu/books/market-structure-and-foreign-trade

Hurlin, C., \& Mignon, V. (2007). Second Generation Panel Unit Roots Tests', Orleans Economics Laboratory, Center 
for Prospective Studies and International Information, Economix. Retrieved from https://halshs-archives-ouvertes.fr/halshs-00159842/

Kao, C. (1999). Cointegration tests applied to panel data cited by Anindya Banerjee in Panel Data Unit Roots and Cointegration: An Overview', published in 2002. https://doi.org/10.1111/1468-0084.0610s1607

Kapri, K. (2016). Productivity. firm size and trade liberalization in a partner country: Evidence from Korean firm-level data. International Review of Economics \& Finance. Elsevier, 45(C), 572-583. https://doi.org/10.1016/j.iref.2016.01.010

Kim, E. (2000). Trade liberalization and productivity growth in Korean manufacturing industries : price protection. market power. and scale efficiency. Journal of Development Economics, 62(1), 55-83. https://doi.org/10.1016/S0304-3878(00)00075-4

Kos à Mougnol, A., \& Kamajou, F. (2016). Determinants Du Developpement Financier Dans Les Pays De La Zone Franc Cfa: Le Role De La Qualite Des Institution. Determinants of Financial Development in the Cfa Franc Zone Countries: The Role of Institutional Quality.

Krugman, P. (1979a). A model of innovation. technology transfer. and the world distribution of income. Journal of Political Economy, 87(2), 253-266. https://doi.org/10.1086/260755

Levin, A, \& Lin, C. F. (1992). Unit Root Test in Panel Data : Asymptotic and Finite Sample Properties. University of California at San Diego. Discussion. Paper No. 92-93.

Levin, A., Lin, C. F., \& Chu, C. S. J. (2002). Unit root tests in panel data: asymptotic and finite-sample properties. Journal of Econometrics, 108(1), 1-24. https://doi.org/10.1016/S0304-4076(01)00098-7

Maddala, G. S., \& Wu, S. (1999). A Comparative Study of Unit Root Tests with Panel Data and a New Simple Test. Oxford Bulletin of Economics and Statistics, 61, 631-652. https://doi.org/10.1111/1468-0084.0610s1631

Miyagiwa, K., \& Ohno, Y. (1995). Closing the technology gap under protection. American Economic Review, American Economic Association, 85(4), 755-770.

N'Guessan, K. R. (2019). Measuring the Degree of International Financial Integration of ECOWAS Countries: An Analysis of the paradox of Feldstein et Horioka (1980). International Journal of Innovation and Applied Studies 26 No.41247-1259. 2019. Innovative Space of Scientific Research Journals. Retrieved from http://www.ijias.issr-journals.org/

Pedroni, P. (1995). Panel cointegration. asymptotic and finite sample properties of pooled time series tests with an application to the PPP hypothesis, Working Paper in Economics, 92-013, Indiana University In : A Dynamic Panel Data Analysis for Relationship between Structural Policy and Economic Growth , (wajdi Bardi et al, 2016), International Journal of Econometrics and Financial Management, 4(1), 1-10.

Pedroni, P. (1999). Critical values for cointegration tests in heterogenous panels with multipleregressors. Oxford Bulletin of Economics and Statistics, Special issue (1999), 0305-904.

Pedroni, P. (2004). Panel cointegration. Asymptotic and finite sample properties of pooled time series tests with an application to the PPP hypothesis. Econometric Theory, 20(3), 597-625. https://doi.org/10.1017/S0266466604203073

Pesaran, M. H. (2007). A simple panel unit root test in the presence of cross-section dependence. Journal of Applied Econometrics, 22(2), 265-312. https://doi.org/10.1002/jae.951

Rodrik, D. (1992). Closing technology gaps: does trade liberalization really help? Trade Policy. Industrialization and Development, New Perspectives. Oxford: Clarendon. Retrieved from http://www.nber.org/papers/w2654.pdf

Rowthorn, R. A., \& Ken, C. (2004). De-industrialisation and the balance of payments in advanced economies. Cambridge Journal of Economics, 28(5), 767-790. https://doi.org/10.1093/cje/beh034

Tahir, M., Ruiz, E. M., Khan, I., \& Afridi, M. A. (2016). The role of trade openness for industrial sector development: panel data evidence from SAARC region. Journal of Asia Business Studies, 10(1), 93-103. https://doi.org/10.1108/JABS-01-2015-0007

Topalova, P., \& Khandelwal, A. (2011). Trade liberalization and firm productivity: The case of India. Review of economics and statistics, 93(3), 995-1009. https://doi.org/10.1162/REST_a_00095

UNCTAD. (2017). United Nations Conferences on Trade and Development, Prosperity for all. Retrieved from https://unctad.org/press-material/facts-figures-0

Westerlund, J., \& David, L. E. (2007). A panel bootstrap cointegration test. Economics Letters, 97(3), 185-190. 
https://doi.org/10.1016/j.econlet.2007.03.003

Wood, A., \& Mayer, J. (2001). Africa's export structure: A comparative perspective. Cambridge, Journal of Economics, 25(3), 369-394. https://doi.org/10.1093/cje/25.3.369

\section{Copyrights}

Copyright for this article is retained by the author(s), with first publication rights granted to the journal.

This is an open-access article distributed under the terms and conditions of the Creative Commons Attribution license which permits unrestricted use, distribution, and reproduction in any medium, provided the original work is properly cited. 